\title{
Effect of Insulator on Thermal Comfort in Poultry House in the Western Region of the State of Paraná
}

\author{
Suélen C. Maino ${ }^{1}$, J. A. C. Siqueira ${ }^{1}$, S. N. M. De Souza ${ }^{1}$, H. Mukai ${ }^{1}$, R. G. R. Da Silva ${ }^{1}$, C. E. C. Nogueira ${ }^{1}$, \\ J. A. A. Dos Santos ${ }^{2}$, M. De Bastiani ${ }^{2}$, C. A. Marques ${ }^{1}$, J. Zanella ${ }^{3}$, E. Seabra Júnior ${ }^{2}$, \\ D. M. Dal Pozzo ${ }^{2} \&$ A. F. Toscan ${ }^{4}$ \\ ${ }^{1}$ Engineering of Energy in Agriculture, State University of West Paraná, Cascavel, Paraná, Brazil \\ ${ }^{2}$ Federal Technological University of Paraná, Medianeira, Paraná, Brazil \\ ${ }^{3}$ Anhanguera University, Campo Grande, Mato Grosso do Sul, Brazil \\ ${ }^{4}$ State University of Santa Catarina, Florianópolis, Santa Catarina, Brazil \\ Correspondence: Suélen C. Maino, Engineering of Energy in Agriculture, State University of West Paraná, Rua \\ Universitária, 2069, Jardim Universitário, CEP: 85819-110, Cascavel, Paraná, Brazil. Tel: 55-453-220-3151. \\ E-mail: suelenmainoarq@live.com
}

Received: July 24, 2018

doi:10.5539/jas.v11n3p289
Accepted: December 19, $2018 \quad$ Online Published: February 15, 2019

URL: https://doi.org/10.5539/jas.v11n3p289

\begin{abstract}
This work was carried out with the objective of evaluating effect of different insulation considering two poultry houses. Two dark house type, located in the western region of the State of Paraná, Brazil were analyzed. The poultry house A1 is characterized with trapezoidal aluzinc cover on the upper side interspersed with a layer of polyurethane and aluminized film on the underside, while the poultry house A2 has cover of aluzinc with black tarpaulin. A thermo-hygrometer was used to measure the temperature and relative humidity of the indoor and outdoor air, and a thermal imager was used to collect the surface temperature data of the birds. In this way, it was possible to evaluate the effect of different insulation of poultry houses on birds. Finally, was concluded that the poultry house A1 provided temperature and relative humidity and temperature of the birds closer to those considered as ideal in the literature.
\end{abstract}

Keywords: poultry, thermal comfort, review

\section{Introduction}

The world production of chicken meat showed high rates in 2015, totaling 88,010 million tons. The highlight of production is the United States of America, followed by Brazil and then by China. Besides the high performance, Brazil also stands out as the main exporter of chicken meat. The records of 2015 show that the country has exported 4,304 million tons, with the state of Paraná as the best performing, accounting for $35.70 \%$ (ABPA, 2016a). Thus, in the midst of such expansion, Brazilian poultry is concerned with serving the most discerning markets, aligning itself with the concepts of sustainability (UBABEF, 2011).

Ministry of Agriculture has set guidelines for poultry welfare and management. By practicing animal welfare, the producer tends to have potential for increased productivity and consequently an improvement in profits. In addition to benefiting from the minimization of losses due to inappropriate management (MAPA, 2008).

The animal submitted to a stressful environment will have impact like slow growth reduction, loss of nutrients, low resistance to diseases and alteration of respiratory rate (Baêta \& Souza, 2010). In this way, it is understood that in addition to genetics, management and nutrition, the interaction between animal and the environment is extremely relevant in animal performance when higher productivity is sought (Baêta \& Souza, 2010; Costa, Dourado, \& Merval, 2012).

For the characterization of the ideal thermal environment for the animal, the effects of wind, radiation, humidity and temperature are considered as important parameters (Baêta \& Souza, 2010). In poultry, temperature control in buildings is considered to be the greatest difficulty in handling broiler chickens (Belusso \& Hespanhol, 2010). Furlan and Macari (2008) reported that for one day old chicks the suitable thermoneutral zone is between $33{ }^{\circ} \mathrm{C}$ to $35{ }^{\circ} \mathrm{C}$ with $65 \%$ to $70 \%$ relative humidity. As they grow and reach between ten and fifteen days of life, the 
temperature belonging to the zone of thermal comfort is reduced between $24{ }^{\circ} \mathrm{C}$ to $33{ }^{\circ} \mathrm{C}$, while for the fourth week of age and after the sixth week, the authors indicate that the recommended temperature becomes between $21{ }^{\circ} \mathrm{C}$ to $22{ }^{\circ} \mathrm{C}$. Studies pointed that birds exposed to high temperatures, from $32{ }^{\circ} \mathrm{C}$ to $38{ }^{\circ} \mathrm{C}$, suffer and may have panic, watery stools, bristling legs, open wings, depression and increased water consumption (Tan et al., 2010). In another experiment, it was observed that birds exposed for three hours at an ambient temperature of $35^{\circ} \mathrm{C}$ showed a state of heat stress, where it was possible to verify the increase in body temperature, respiratory alteration, and a dispersed distribution in the cage (Han et al al., 2010).

Hence, it is important to analyze the particularities of each region to choose the appropriate building system (Neufert, 2005; Tinoco, 2001). In this sense, the architectural layout of the poultry house should have a strong potential for heat and ventilation control (The Poltry Site, 2008). The different constructive typologies are characterized by the variability of technologies and operating systems adopted in the poultry house, and can be classified in conventional, semiclimatized or automated systems, climatized, dark house and blue house (Garcia \& Ferreira Filho, 2005; V. M. N. Abreu \& P. G. Abreu, 2011). In the dark house system the use of energy generator becomes indispensable. This system adopts the use of controllers that perform functions in all the internal sectors. The feeders are automatic and the nipple system was used for watering. For the cooling system, nebulization or pad cooling associated with negative pressure exhausters can be used. The use of baffles may or may not occur. The light intensity control system is performed by the use of dimmer. The curtains are completely sealed, not allowing the entrance of light and air, usually in black polyethylene on one side and silver on the other (V. M. N. Abreu \& P. G. Abreu, 2011). The production of birds in controlled facilities usually provide superior performance as compared to birds produced in naturally ventilated environments, and this is due to the fact that ideal bird comfort conditions can be maintained (Glatz \& Pym, 2007).

As for the roofing system, the roof is the constructive component that represents greater relevance in an installation focused on poultry, and this is due to the area coverage that receives solar radiation (Sampaio, Cardoso, \& Souza, 2011). Studies indicate that a solution to control internal temperature of the poultry house, is to use white paint on the external surfsce. In asbestos roofs, the temperature was reduced by up to $9{ }^{\circ} \mathrm{C}$ at the $1 \mathrm{pm}$ (Sarmento et al., 2005). The high efficiency in the reduction of internal temperature was also observed with ceramic tiles and fiber cement, making them recommended to cover animal production facilities (Sampaio, Cardoso, \& Souza, 2011). However, in the case of broiler birds, it is observed that the use of paint exclusively does not present efficiency when evaluated on comfort indexes considered as ideal (Baêta \& Souza, 2010). In this way, it is evident the necessity of the adequate choice of roofing materials (Tinoco, 2001) that in certain cases can receive lining systems as an option to reinforce the heat exchange barrier (Baêta \& Souza, 2010), or the use of insulating materials attached to the roof tile, composing a roof tile in the sandwich model.

In this sense, in order to collaborate with poultry production for high productivity and animal welfare related to the thermal stress, poultry house architecture planning is associated with the choice of an effective coverage system. Therefore, the present research starts from the premise that different systems of covering and wrap presents different behaviors regarding thermal performance. The aim of this study was to evaluate two dark house systems, one with a typical cover, one with a tarpaulin, and the other with a roof with thermoacoustic tiles, consolidating the information serving as a contribution to the producers, managers of poultry projects and other professionals in the sector. Finally, the objective was to evaluate the parameters of comfort in the poultry houses, considering the average internal temperature, internal average relative humidity and the average temperature of the bird.

\section{Material and Methods}

\subsection{Location of Experiments}

The study was conducted in two dark house chicken broilers belonging to the same cooperative, located in the municipality of Missal, in the western region of the State of Paraná, Brazil. The geographical coordinates of the poultry house A1 can be identified by latitude $25^{\circ} 3^{\prime} 15^{\prime \prime}$ and longitude $54^{\circ} 15^{\prime} 40^{\prime \prime}$ to the west, oriented west-east, and poultry house A2 by latitude $25^{\circ} 4^{\prime} 48^{\prime \prime}$ to the south and longitude $54^{\circ} 11^{\prime} 32^{\prime \prime}$ to West, oriented East-West. Data collection was performed during the summer of 2017 in the months of December and January.

According to the classification of Koppen and Geiger the climate in Missal is warm and temperate of the type $\mathrm{Cfa}$ (Subtropical climate with hot summer), with an average temperature of $20.2{ }^{\circ} \mathrm{C}$. There is significant rainfall during the year in the municipality, even in July which is the driest month, having an annual average of $1734 \mathrm{~mm}$. The highest average temperature is $24.6{ }^{\circ} \mathrm{C}$ and occurs in January, while the lowest average temperature is 15.3 ${ }^{\circ} \mathrm{C}$ and occurs in June (Climate Data ORG, 2017). 


\subsection{Poultry House Constructive Characteristics}

The poultry house A1 (Figure 1) houses 21,500 birds and poultry house A2 (Figure 2) 33,600 birds, Near the production space there are also support environments such as control room, home heating and cooling system, and tanks for equipment and products used to poultry house maintainance. The facilities have the same size, being 16 meters wide and 150 meters long, totaling 2,400 square meters of area suitable for the poultry development.

The poultry houses have precast concrete structure and pillars arranged in 30 spans with spacing of $5 \mathrm{~m}$. The system of sealing is in masonry of ceramic block and the floor is of beaten earth with overlapping of wood shaving bed.

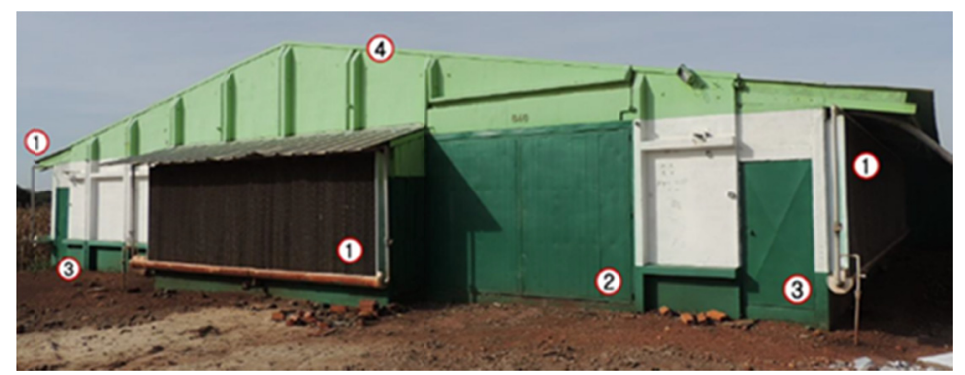

Figure 1. West-east elevation of the poultry house A1. Detail of the front facade. (1) Pad cooling (2) Maintenance door from housing to the slaughter (3) Access door to the pad cooling (4) Precast concrete structure

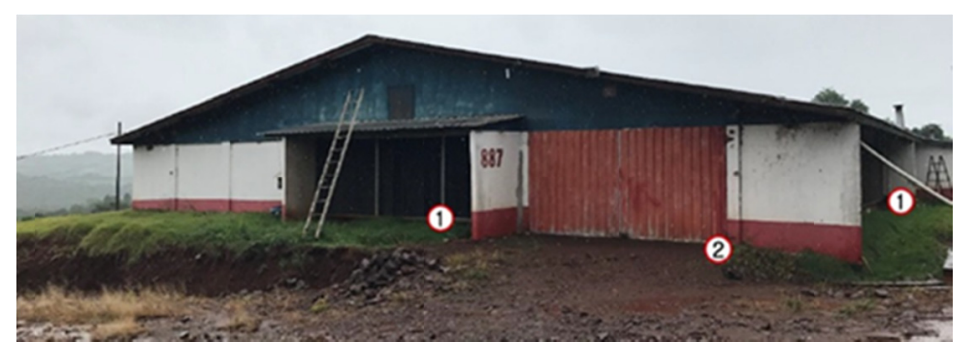

Figure 2. East-west elevation of the poultry house A2. Detail of the front facade. (1) Pad cooling (2) Gateway

The insulation model that accompanies the brick work fence of the poultry house A1, and defines as a dark house, is composed of black polyethylene curtain on the outside and reflective, as well as the Y type band with the same configuration (Figure 3). The poultry house A2 has as characteristics the curtain of the poultry house A1, but the Y type band has black eaves on the inner side and reflective on the external side (Figure 4).
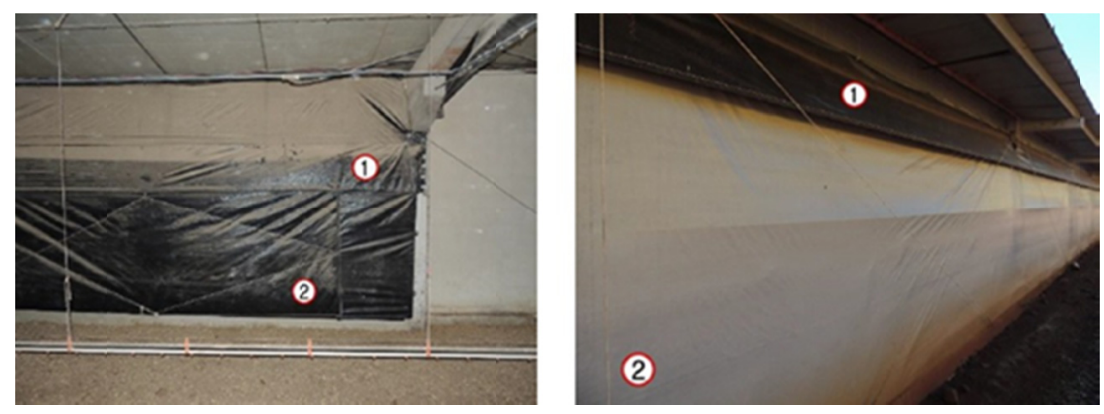

Figure 3. Side sealing of the poultry house A1. Detail of the side sealing. (1) Y type band in black color (2) Curtain internal face in black color and external face in silver color 

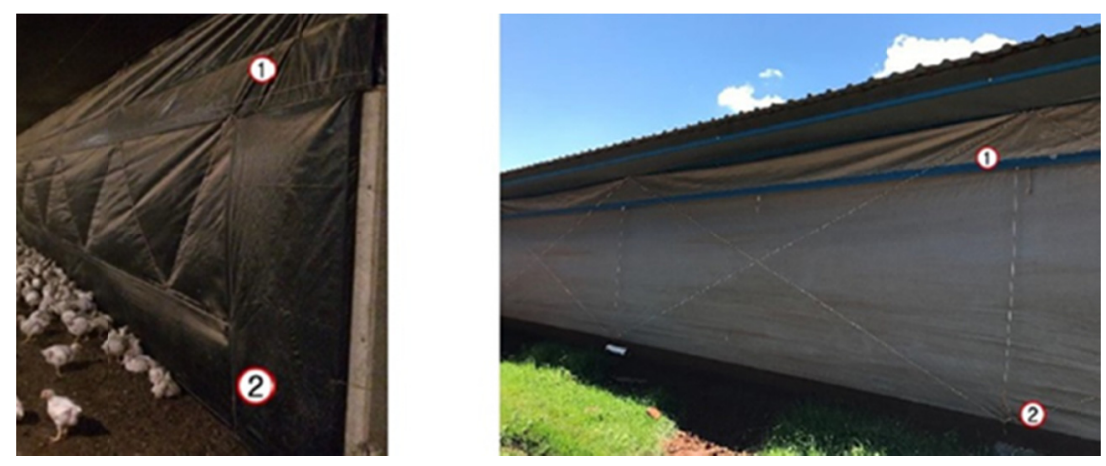

Figure 4. Side sealing of the poultry house A2. Detail of the side sealing. (1) Y type band with eaves internal face in black color and external face in silver color (2) Curtain internal face in black color and external face in silver color

The poultry house Ai cover system consists of a metallic structure and thermo acoustic tile, which is formed by TRP 35 trapezoidal aluzinc on the upper side, interspersed with a polyurethane layer with a density of 36 to 42 $\mathrm{kg} / \mathrm{m}^{3}$ and aluminized film on the side (Figure 5). There are also air reflectors in black canvas and triangular format that accompany the slope of the roof. The right foot free of the poultry house with 2.85 meters.

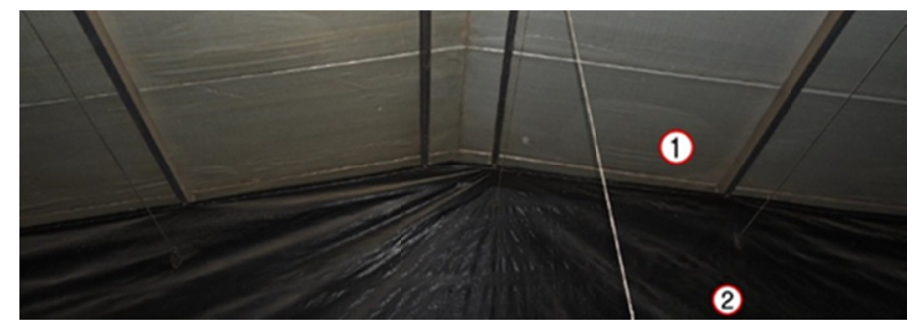

Figure 5. Rooftop system of the poultry house A1-thermoacoustic tile. (1) Aluminized film on the bottom layer of the thermoacoustic tile (2) Air reflector in triangular format (accompanies the slope of the rooftop) on black canvas

The poultry house A2 uses TRP 40 trapezoidal aluzinc with lining and air reflectors on black canvas (Figure 6), and unlike poultry house A1, the reflectors are in rectangular format with a dimension of 1.10 meters and the right free foot is 2,80 meters.

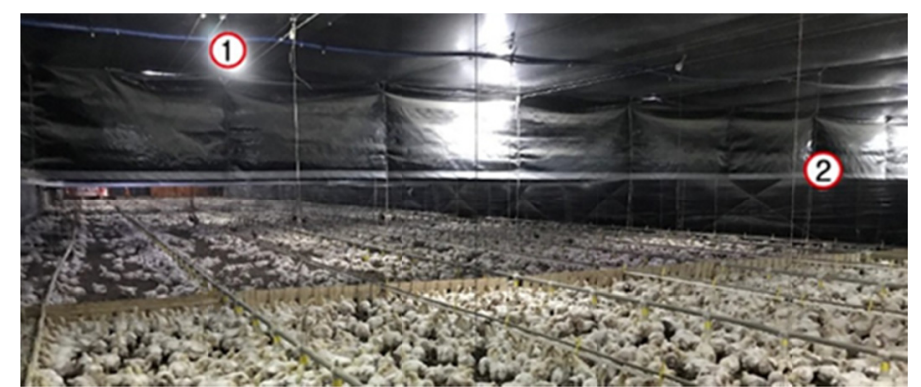

Figure 6. Rooftop system of the poultry house A2 - aluzinc tile with canvas ceiling. (1) Black canvas ceiling (2) Air reflector in rectangle format on black canvas

\subsection{Poultry House Technical Characteristics}

\subsubsection{Poultry House A1}

The poultry house is monitored through an environment control panel of poultry brand Inobram, model SMAAI 4. The automation system allows to define the ideal temperature and humidity according to the poultry age, and 
based on this the controller promotes the drives of the following interconnected functions: probes, alarm, heating and cooling system, ventilation, nebulizers and nutrition system.

A wood oven (model Agrobona AB 38-00) was used as heating system for poultry house A1. The heater is located after the first three spans of the pre-cast structure, in the range of 15 meters. The cooling system is formed by Big Dutchman brand nebulizers and distributed throughout the entire poultry house. Besides the nebulizers that control the temperature and internal humidity of the installation, there is also the pad cooling system also of the Big Dutchman brand, which is composed of evaporative cellulose panel and that are arranged in three faces of the poultry house, however only two are in operation (Figure 7).

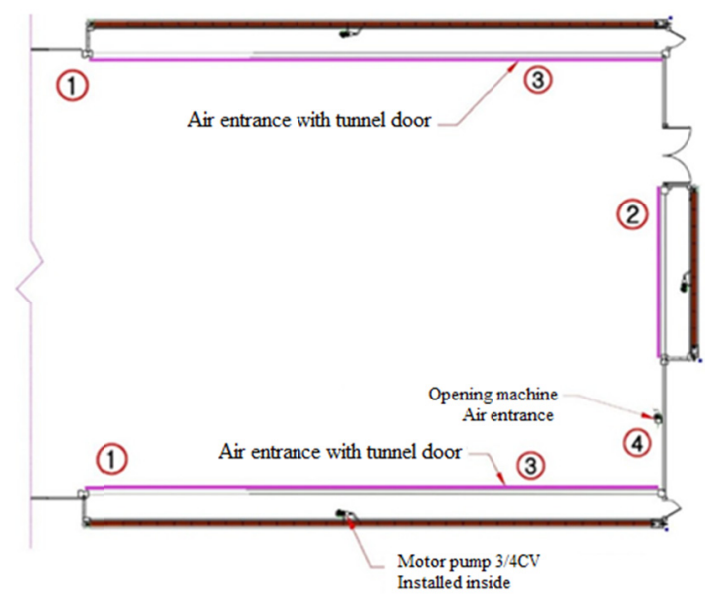

Figure 7. Cooling system—Pad cooling. Distribution sketch. (1) Active pad cooling evaporative panels

(2) Disabled pad cooling evaporative panels (3) Tunnel door ventilation system

(4) Tunnel door opening machine of air

As shown in the sketch of the pad colling, one can observe the distribution of the tunnel door ventilation system and also the air intake machine, which is automatically activated by the controller panel, which identifies the internal temperature variation of the poultry house. The pad colling cooling system is installed on the sides of the building and is 15 meters long, while the front system, which is deactivated, is 5.50 meters and the maintenance space, together with the refrigerated air three sides of the poultry house, cover 80 centimeters (Figure 8).

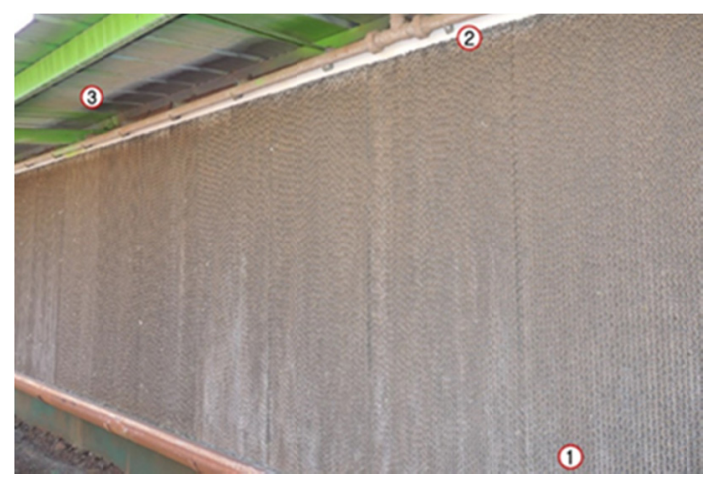

Figure 8. Cooling system—Pad cooling. Cellulose evaporative panels' side view. (1) Cellulose boards (2) Pad cooling hydraulic network system (3) Aluzinc tile trapeze TRP 35 with eaves with one meter

The A1 exhaust fans are Big Dutchman, model 50 " $70^{\text {th }}$ with cone and are arranged on the side faces of the building, opposite the main access. Each face has five exhaust fans and there is also space for the installation of two more exhausting machines on each face.

The lighting system is composed of dimmerized LED lamps of the brand American LED, with 8 Watts of power each. The distribution occurs with four lamps arranged in 30 lines, totaling 120 luminaires. As for the color 
temperature, in most of the aviary can be seen the use of cold lamps with $5.700 \mathrm{~K}$, however, there is also the use of hot lamps with $3,000 \mathrm{~K}$. The control system for indoor temperature adjustment and light intensity is a dimmer, model I-800, Inobram brand, and is interconnected to the controller panel.

The nutrition system comes from the distribution of four lines of automatic feeders HI-LO, model Unigrow 360 , totaling 1,000 dishes installed throughout the poultry house. There are also the drinkers, model 7078, which are arranged in five lines and totaling 3,250 nipples. The silos of supply and storage of the poultry house have capacity for 16 tons of feed. All equipments related to the nutrition system are of the Big Dutchman brand.

The water supply of the building comes from artesian well. The water is pumped into a polyethylene reservoir with a capacity of 20,000 liters. To supply the drinkers, the water from the larger reservoir is directed to a water tank with a capacity of 2,000 liters. As for the hydraulic supply of the cooling systems-nebulizers and evaporative plates - the water from the larger reservoir is channeled into a water box with a capacity of 1,000 liters. Lastly, the poultry plant has a synchronous generator system of the NEW BEI line of the Nova brand, which helps to maintain the poultry house in the event of a power failure.

\subsubsection{Poultry House A2}

The controller panel of poultry house A2 has the same characteristics as A1. As previously explained, the Inobram brand, model SMAAI 4, allows the optimum temperature and humidity to be defined according to the bird's age, as well as to drive the other interconnected functions.

The heating system is based on the use of a wood oven and the model used is Agrobona AB 2614, which has a duct with two hot air outlets. Like the poultry house A1, the heater is located after the first three spans of the pre-cast structure, in the range of 15 meters.

The cooling system consists of Big Dutchman brand nebulizers distributed throughout the building. There is also the Big Dutchman's pad cooling system for internal temperature and humidity control, which consists of an evaporative cellulose panel and integrated operation of the hand-operated curtains that aid in the intake of air (Figure 9).

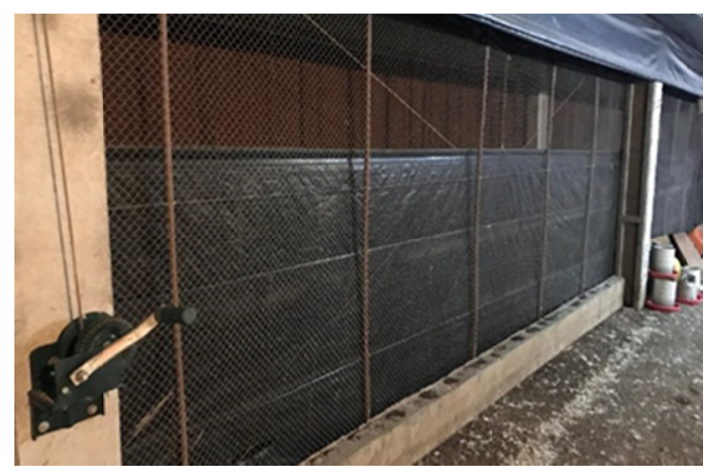

Figure 9. Cooling system_-Pad cooling with manual air control

The pad colling system is arranged on three sides of the poultry house (Figure 10), on the sides of the building the panel contemplates 15 meters in length, while the front face has 4 meters, and the maintenance space and refrigerated air duct on the three faces of the installation, cover 80 centimeters. 


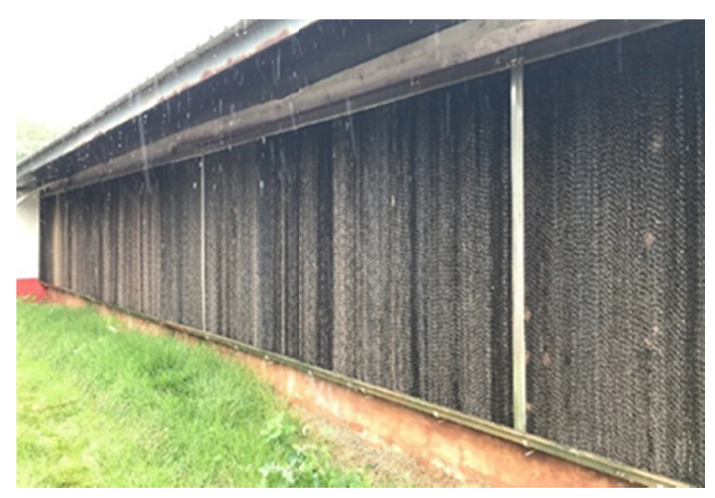

Figure 10. Cooling system-Pad cooling

The poultry house A2 exhaust fans have the same characteristics as A1. The machines are Big Dutchman, model 50 " $70^{\text {th }}$ with cone and are arranged on the side faces of the building, opposite the main access. Each face has five exhaust fans, totaling ten units.

Like the poultry house A1, the lighting system is made up of dimmerized American LED lamps, each with 8 watts of power. The distribution occurs with four lamps arranged in 30 lines, totaling 120 luminaires. As for the color temperature, in most of the house can be seen the use of cold lamps with $5.700 \mathrm{~K}$, however, there is also the use of hot lamps with 3,000 K. The system for control, temperature adjustment and intensity of Inner lighting occurs through a dimmer, model I-800, of the Inobram brand, which is interconnected to the controller panel.

The nutrition system runs through the distribution of four lines of automatic feeders, model Corti Sintese, totaling 778 dishes installed throughout the poultry house. There are also, drinkers, model $4006 \mathrm{H}$, which are arranged in five lines and totaling 2,807 nipples. The silos of supply and storage of the poultry house have capacity for 16 tons of feed. All equipment related to the nutrition system is Avioeste brand.

The water supply of the building comes from artesian well. Similarly to A1, the water is pumped into a polyethylene reservoir with a capacity of 20,000 liters. To supply the drinkers, the water from the larger reservoir is directed to a water tank with a capacity of 2,000 liters. Unlike the A1 poultry house, the hydraulic supply of the cooling systems - nebulizers and evaporative plates - is channeled from the larger reservoir into a 500-liter water tank. Lastly, the poultry plant has a generator system of the Stemac brand, model DS 7320, which helps to maintain the poultry house in the event of a power failure.

\subsubsection{Technical Specifications of the thermal Imager Used for Poultry Temperature Measurement}

The Irisys IRI 4030 thermal imager (Figure 11) was used to perform the data collection on the surface temperature of the birds, which has an uncooled microbolometer detector that provides images of quality and performance regarding the measurement being indicated for high temperature measurements. has a range of -10 ${ }^{\circ} \mathrm{C}$ to $250{ }^{\circ} \mathrm{C}$. The generated images can be processed to other mechanisms through MMC (Multi Media Card) and SD (secure digital) cards allowing in-depth data analysis, reporting and printing of generated material (IRISYS, 2010).
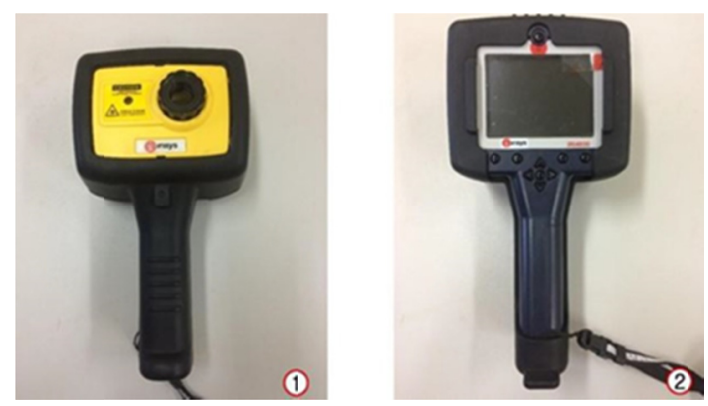

Figura 11. Thermovisor Irisys IRI 4030 (1) Equipment front view (2) Equipment back view 
2.3.4 Technical Specifications of the Thermo-Hygrometer Used for Temperature and Relative Humidity Measurement Inside the Poultry Houses

For the measurement of the internal temperature and the relative humidity inside the poultry house a Thermo-hygrometer THDL-400 Environment Meter of the brand Instrutherm was used. The relative humidity sensor allows you to measure values in the range of $25 \%$ to $95 \%$. The temperature sensor measures values in the range $-20^{\circ} \mathrm{C}$ to $750{ }^{\circ} \mathrm{C}$ (Figure 12).

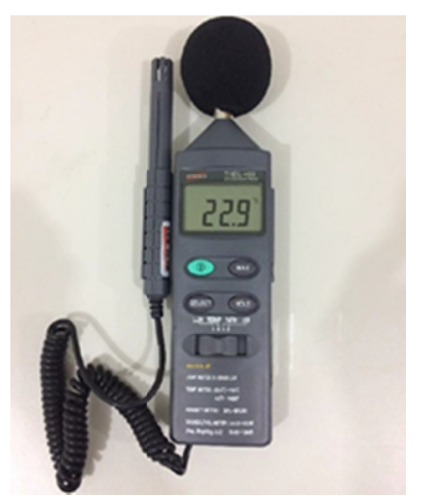

Figure 12. Thermo-hygrometer Instrutherm THDL-400 Environment Meter

2.3.5 Method of Measuring the Temperature and the Internal and External Relative Humidity of the Environment and the Temperature of the Birds in the Poultry Houses

Throughout the 150 meters extension of the $\mathrm{A} 1$ and $\mathrm{A} 2$ poultry house, 16 points were demarcated every 10 meters in order to collect the data regarding the temperature of the birds, temperature and relative humidity of the internal and external air. In order to collect the temperature and the relative air humidity of the poultry houses, two operators, one inside and the other outside, were simultaneously equipped with a THDL-400 thermo-hygrometer for recording temperatures in triplicate in 16 points and 1 meter high from the floor level. Based on the measurements an average of temperature per point can be ploted and later, an average of temperature per day of data collection. For the survey of the temperature of the birds, the operator, located in the internal environment and equipped with the thermal imager, directed the sensor to the bird and then registered thermographic images, at random, in the 16 demarcated points. From the thermographies and with the help of the Irisys 4000 Series Imager software, a random image was also selected per week of collection and, thus, the temperature of greater relevance can identified. In Table 1 it is possible to verify the information pertinent to the dates and age of the birds during the collection of data.

Table 1. Dates and birds age during the data collection of temperature and internal and external relative humidity in the poultry houses, and the bird's temperature in the poultry house A1 and A2

\begin{tabular}{|c|c|c|c|c|}
\hline & & \multicolumn{3}{|c|}{ Week } \\
\hline & & 1 & 2 & 3 \\
\hline \multirow{2}{*}{ Poultry house A1 } & Housing date $13 / 12 / 2017$ & $16 / 12 / 2017$ & $20 / 12 / 2017$ & $04 / 01 / 2018$ \\
\hline & Birds age (Days) & 4 & 8 & 23 \\
\hline \multirow{2}{*}{ Poultry house A2 } & Housing date $15 / 12 / 2017$ & $23 / 12 / 2017$ & $27 / 12 / 2017$ & $04 / 01 / 2018$ \\
\hline & Birds age (Days) & 9 & 13 & 21 \\
\hline
\end{tabular}

\subsubsection{Data Analysis}

For the organization of the data in spreadsheets and elaboration of graphs to analyze the effect of the cover and enclosure in the thermal comfort of the poultry houses was used Excell software. On the other hand, the information collected regarding temperature and relative humidity, both internal and external were analyzed by the coefficient of variation. 


\section{Results and Discussion}

The average values of the temperatures $\left({ }^{\circ} \mathrm{C}\right)$ and the relative humidity $(\%)$, internal and external, obtained for the poultry houses A1 and A2, through the thermohygrometer, can be observed in Table 2 .

From the interaction of the data between the two poultry houses, it can be seen that in the first week of data collection, the behavior of the average external temperatures showed the value of $37^{\circ} \mathrm{C}$ for poultry house $\mathrm{A} 1$ and $28{ }^{\circ} \mathrm{C}$ for poultry house $\mathrm{A} 2$, while average internal temperatures recorded in the first week in $\mathrm{A} 1$ and second week in A2 were $34.3{ }^{\circ} \mathrm{C}$ and $29.3{ }^{\circ} \mathrm{C}$, respectively. Based on the premise that the poultry plant that favors chick development at the thermoneutrality temperature according to age has a better thermal performance, it can be verified that the poultry house A1 presented internal average temperature for the first week of data collection, which were close to those considered as ideal when related to the parameter from $33{ }^{\circ} \mathrm{C}$ to $35{ }^{\circ} \mathrm{C}$, while the poultry house A2 presented values slightly below those recommended from $30{ }^{\circ} \mathrm{C}$ to $33{ }^{\circ} \mathrm{C}$ (Macari \& Furlan, 2001; Bedin, 2015).

Table 2. Average internal and external temperature and relative humidity in the poultry houses A1 and A2 in the first three weeks of birds housing

\begin{tabular}{|c|c|c|c|c|c|c|c|c|}
\hline \multirow{3}{*}{ Week } & \multicolumn{4}{|c|}{ External } & \multicolumn{4}{|c|}{ Internal } \\
\hline & \multicolumn{2}{|c|}{ Temperature $\left({ }^{\circ} \mathrm{C}\right)$} & \multicolumn{2}{|c|}{ Relative humidity (\%) } & \multicolumn{2}{|c|}{ Temperature $\left({ }^{\circ} \mathrm{C}\right)$} & \multicolumn{2}{|c|}{ Relative humidity (\%) } \\
\hline & A1 & A2 & A1 & A2 & A1 & A2 & A1 & $\mathrm{A} 2$ \\
\hline 1 & 37.0 & 28.0 & 33.0 & 84.7 & 34.3 & 29.3 & 64.6 & 78.7 \\
\hline 2 & 27.5 & 26.3 & 83.9 & 84.6 & 29.4 & 26.9 & 78.8 & 82.3 \\
\hline 3 & 33.8 & 31.1 & 41.1 & 46.0 & 31.3 & 29.0 & 63.6 & 68.4 \\
\hline Average & 32.8 & 28.5 & 52.7 & 71.7 & 31.7 & 28.4 & 69.0 & 76.4 \\
\hline Standard Deviation & 4.8 & 2.5 & 27.4 & 22.3 & 2.5 & 1.3 & 8.5 & 7.2 \\
\hline C.V. (5) & 14.7 & 8.6 & 52.0 & 31.1 & 7.9 & 4.7 & 12.4 & 9.4 \\
\hline
\end{tabular}

In the second week of data collection, mean external temperatures presented data of $27.5^{\circ} \mathrm{C}$ for poultry house A1 and $26.3{ }^{\circ} \mathrm{C}$ for poultry house $\mathrm{A} 2$, and average internal temperatures recorded were $29.4^{\circ} \mathrm{C}$ for the first week of life of the bird in poultry house A1 and of $26.9^{\circ} \mathrm{C}$ for the second week of life of the bird in the poultry house A2. According to the parameters of $30^{\circ} \mathrm{C}$ to $33^{\circ} \mathrm{C}$ (Macari \& Furlan, 2001; Bedin, 2015), it was verified that the two poultry house were below the conditions recommended for the development of the bird according to age, but it can be observed that the average temperature collected in poultry house A1 is closer to the ideal minimum value.

The behavior of the average external temperatures, on the third week of life of the bird and the data collection, registered $33.8{ }^{\circ} \mathrm{C}$ for the poultry house $\mathrm{A} 1$ and $31.1^{\circ} \mathrm{C}$ for the poultry house A2. The average internal temperatures were between $31.3{ }^{\circ} \mathrm{C}$ for the poultry house $\mathrm{A} 1$ and $29^{\circ} \mathrm{C}$ for the poultry house A2. Thus, following the foundations of $27^{\circ} \mathrm{C}$ to $30^{\circ} \mathrm{C}$ (Macari \&Furlan, 2001; Bedin, 2015) it was verified that the poultry house A2 met the desirable values for the development of the bird according to the age.

Finally, it can be concluded that poultry house A1 showed an average internal temperature closer to that considered as ideal. In Figure 13 it is possible to visualize the internal average temperature variation registered in the poultry houses, during the three weeks of collection, with the comparison of the recommended values according to Macari and Furlan (2001; Bedin, 2015). 


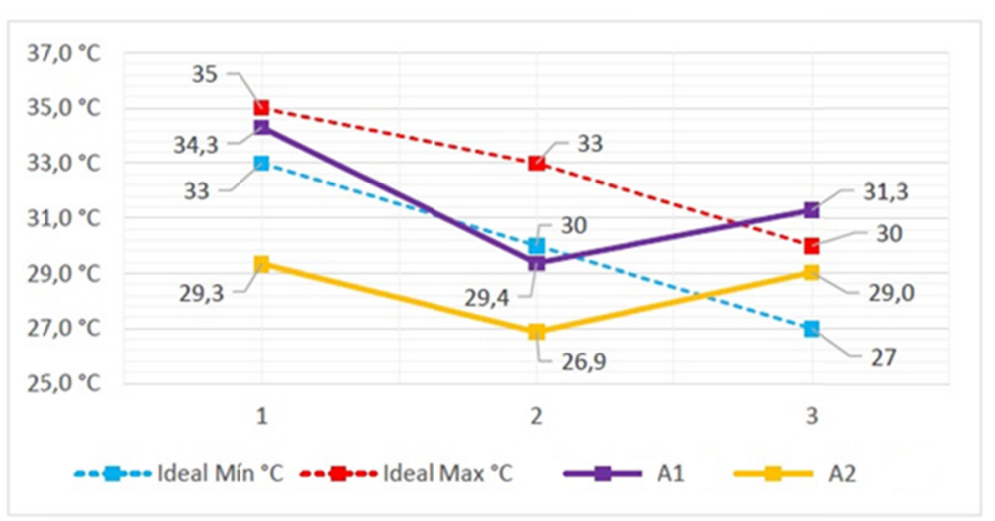

Figure 13. Internal average temperature variation recorded in the poultry houses A1 and A2, during the three weeks of data collection, with the comparison of the values considered as ideal

When considering the interaction of the data concerning the average relative humidity collected in the poultry houses, it can be observed that poultry house A1 registered $64.4 \%, 78.8 \%$ and $63.3 \%$ and poultry house A2, $78.7 \%, 82.3 \%$ and $68.4 \%$ in the first, second and third week of survey, respectively. According to a study by Abreu and Abreu (2011), the values for internal relative humidity of the air, considered as ideal during the seven-week cycle of the bird's life is $60 \%$ to $70 \%$. In this way, poultry house A1 showed a value closer to the recommended conditions when compared to A2 in the first week of data collection. In the second week, the poultry houses showed higher values than those reported in the literature, and finally, in the third week, both were within the suggested parameters, the value of the poultry house A1 being $63.6 \%$ closer to the ideal average and the poultry house A2 of $68.4 \%$ closest to the maximum recommended relative humidity. As Nascimento (et al., 2012) suggests, birds dissipate heat through evaporation, and this in turn depends on the relative humidity of the air. Thus, when the relative humidity of the environment is high, the bird changes the maintenance process of homeothermia dissipating the air through the airways; therefore they cause a higher respiratory rate and may compromise their performance. Finally, it can be concluded that poultry house A1 showed the average internal relative humidity closer to the ones considered as ideal. In Figure 14 the variation of the internal mean relative humidity recorded over the three weeks in the poultry housea can be visualized together with the comparison of the values considered as ideal according to Abreu and Abreu (2011).

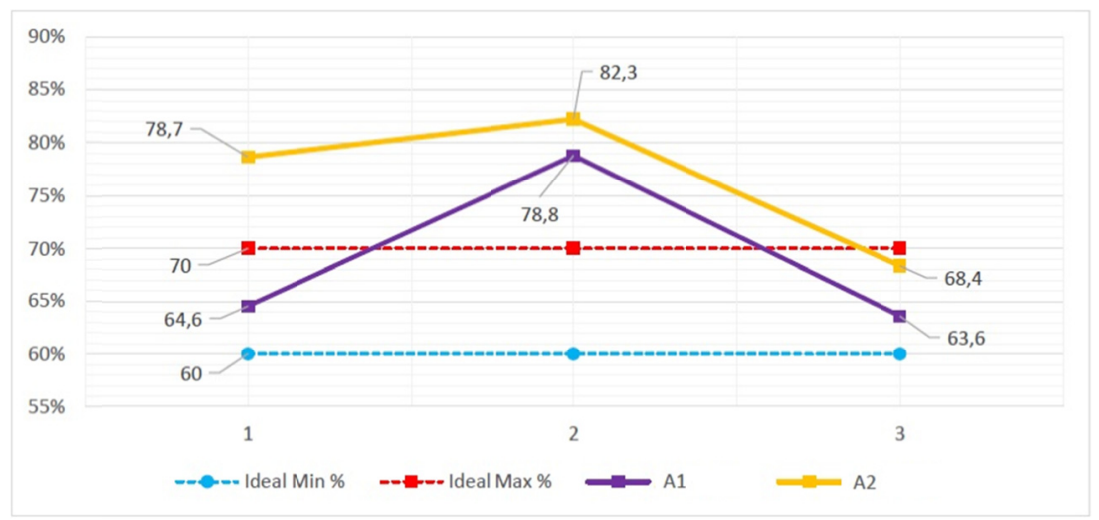

Figure 14. Internal average relative humidity variation recorded in the poultry houses A1 and A2, during the three weeks of data collection, with the comparison of the values considered as ideal

The values for poultry house A1 and A2 surface temperature were obtained through the Irisys IRI 4030 thermal imager and can be observed in Table 3 and also in the thermographs corresponding to each week of data collection (Figures 15 and 16). For Cobb-Vantress (COBB, 2013) the internal temperature of the newly incubated chick should range from $40{ }^{\circ} \mathrm{C}$ to $41{ }^{\circ} \mathrm{C}$ increasing to $41{ }^{\circ} \mathrm{C}$ to $42{ }^{\circ} \mathrm{C}$ during the first and fifth day. 
When the internal temperature of the chick is above $41^{\circ} \mathrm{C}$, it becomes hot and breathless, and when the chick's internal temperature falls below $40^{\circ} \mathrm{C}$ it is indicating it's cold.

When compared to the ideal index for the first five days of life of the bird, poultry house A1 presented the superficial temperature of the birds slightly below, with a value of $39.2{ }^{\circ} \mathrm{C}$, but close to the level of comfort of the chick, while poultry house A2 had the surface temperature recorded at $36{ }^{\circ} \mathrm{C}$. For the second week we can observe the values of $40.2{ }^{\circ} \mathrm{C}$ in the $\mathrm{A} 1$ and $39.3{ }^{\circ} \mathrm{C}$ for the $\mathrm{A} 2$. In the third week of the data collection, the results were $39.4{ }^{\circ} \mathrm{C}$ for the $\mathrm{A} 1$ and $35.9{ }^{\circ} \mathrm{C}$ for the A2. Finally, it can be concluded from all recorded data that the poultry house A1 showed comfort values in the birds during the first three weeks of life that were closer to the ideal ones.

Table 3. Surface temperature of the bird in the poultry houses A1 and A2 during the three weeks of birds housing

\begin{tabular}{lll}
\hline \multirow{2}{*}{ Week } & \multicolumn{2}{c}{ Bird surface temperature (\%) } \\
\cline { 2 - 3 } & Poultry house A1 & Poultry house A2 \\
\hline 1 & 39.3 & 36.0 \\
2 & 40.2 & 39.3 \\
3 & 39.4 & 35.9 \\
\hline
\end{tabular}
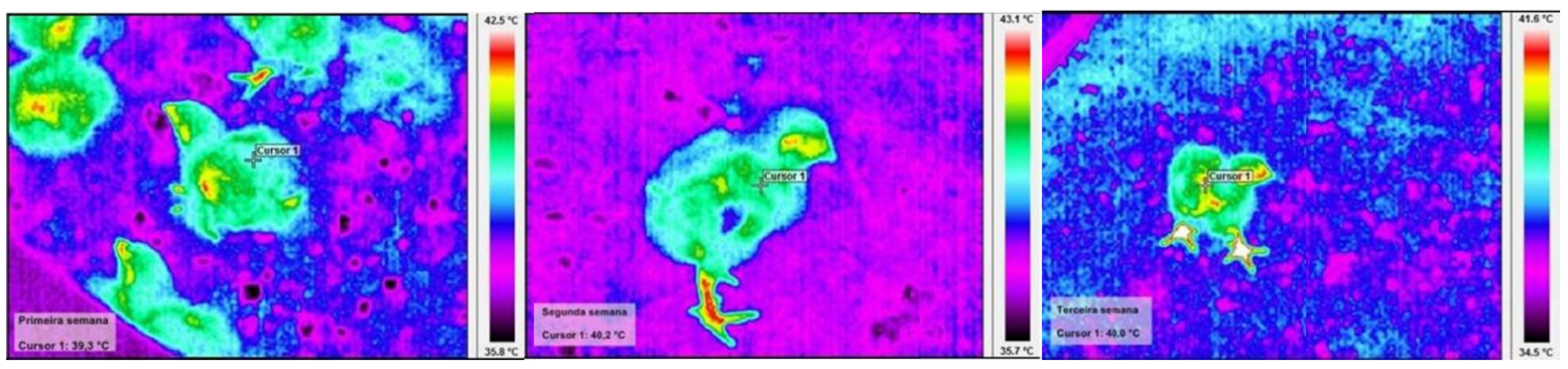

Figure 15. Thermograms obtained in the poultry house A1 for the first, second and third week of data collection with the surface temperature obtained, respectively
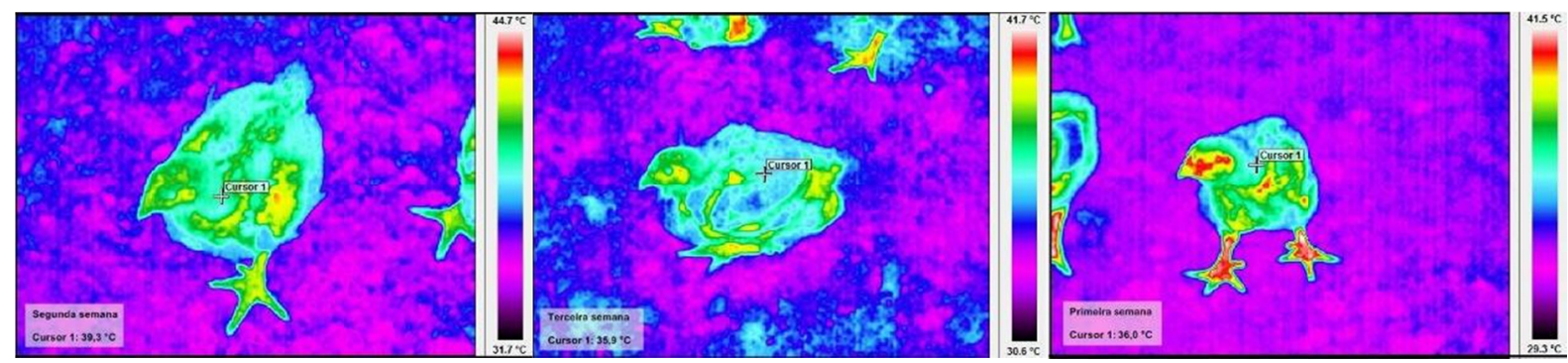

Figure 16. Thermograms obtained in the poultry house A2 for the first, second and third week of data collection with the surface temperature obtained, respectively

\section{Conclusion}

According to study the following conclusions can be drawn: poultry house A1, with thermal insulation on the roof, presented an average internal temperature closer to those considered ideal, indicating the values of $34.3{ }^{\circ} \mathrm{C}$, $29.4{ }^{\circ} \mathrm{C}$ and $31.3{ }^{\circ} \mathrm{C}$ for the first, second and third week of data collection, respectively, while A2, without thermal insulation on the roof, presented the values of $29.3{ }^{\circ} \mathrm{C}, 26.9{ }^{\circ} \mathrm{C}$ and $29.0^{\circ} \mathrm{C}$.

As for the average internal relative humidity, the poultry house A1 showed the closest results to those considered ideal in the literature, with records of $64.4 \%, 78.8 \%$ and $63.6 \%$, while poultry house A2 showed values of $78.7 \%$, $82.3 \%$ and $68.4 \%$ according to the first, second and third week of data collection, respectively. In general, poultry house $\mathrm{A} 1$ that showed conditions of thermal comfort for the birds, during the first three weeks, closer to those considered ideal, with $39.3{ }^{\circ} \mathrm{C}, 40.2{ }^{\circ} \mathrm{C}$ and $39.4{ }^{\circ} \mathrm{C}$, while the poultry house $\mathrm{A} 2$ showed values of $36.0^{\circ} \mathrm{C}$, $39.3{ }^{\circ} \mathrm{C}$ and $35.9{ }^{\circ} \mathrm{C}$. It is important to follow a complete housing cycle of broilers in dark house type poultry 
house, with and without thermal insulation on the roof, to observe characteristics and performance over the phases of bird development.

\section{References}

ABPA (Brazilian Association of Animal Proteins). (2016a). 2016 Annual report. Retrieved from http://abpa-br. com.br/storage/files/abpa_relatorio_anual_2016_ingles_web_versao_para_site_abpa_bloqueado.pdf

Abreu, V. M. N., \& Abreu, P. G. (2011). The ambience challenges on bird systems in Brazil. Brazilian Journal of Animal Science, 40, 1-14.

Baêta, F. C., \& Souza, C. F. (2010). Ambience in rural buildings: Animal comfort (2nd ed.). Vicosa, MG: Publishing Company UFV.

Belusso, D., \& Hespanhol, A. N. (2010). The evolution of Brazilian industrial poultry production and its territorial effects. Percurso Magazine (Vol. 2, No. 2). Maringá, PR: NEMO.

Climate Data ORG. (2017). Location. Retrieved from https://pt.climate-data.org/location/43581/

Costa, E. M. S., Dourado, L. R. B., \& Merval, R. R. (2012). Measures to evaluate thermal comfort in birds (218 ed.). Londrina, PR: PUBVET.

Furlan, R. L., \& Macari, M. (2008). Thermoregulation. In M. Macari, R. L. Furlan, \& E. Gonzales (Eds.), Avian physiology applied to broilers (2nd ed., pp. 209-230). Jaboticabal: FUNESP.

Garcia, L. A. F., \& Ferreira Filho, J. B. S. (2005). Economies of scale in the production of broilers in Brazil. Economy and Rural Sociology Magazine, Brasilia, 43(3), 465-483. https://doi.org/10.1590/S0103-200320 05000300004

Glatz, P., \& Pym, R. (2007). Poultry housing and management in developing countries. Poultry Development Review, 1-5.

Han, A. Y., Zhang, M. H., Zuo, X. L., Zheng, S. S., Zhao, C. F., Feng, J. H., \& Cheng, C. (2010). Effect of acute heat stress on calcium concentration, proliferation, cell cycle, and interleukin-2 production in splenic lymphocytes from broiler chickens. Poultry Science, 89(10), 2063-2070. https://doi.org/10.3382/ps. 2010-00715

MAPA (Ministry of Agriculture, Livestock and Supply). (2008). Normative Instruction No 56, de 06 de November of 2008. Retrieved from http://www.agricultura.gov.br/assuntos/sustentabilidade/bem-estaranimal/arquivos/arquivos-legislacao/in-56-de-2008.pdf

Neufert, P. (2005). Art of Designing in Architecture (17 ed.). Barcelona: Ed. Gustavo Gili.

Sampaio, C. A. P., Cardoso, C. O., \& Souza, G. P. (2011). Surface temperatures of tiles and their relation with the thermal environment. Agricultural Engineering, 31(2), 230-236.

Sarmento, L. G. V., Dantas, R. T., Furtado, D. A., Nascimento, J. W. B., \& Silva, J. H. V. (2005). Effect of the exterior painting of the roof on the climatic environment and the performance of broiler chickens. Agropecuária Técnica, 26(2), 117-122.

Tan, G. Y. L., Yang, L., Fu, Y. Q., Feng, J. H., \& Zhang, M. H. (2010). Effects of different acute high ambient temperatures on function of hepatic mitochondrial respiration, antioxidative enzymes, and oxidative injury in broiler chickens. Poultry Science, 89, 115-122. https://doi.org/10.3382/ps.2009-00318

The Poultry Site. (2008). Heat stress. Retrieved from http://www.thepoultrysite.com/articles/1192/heat-stress

Tinoco, I. F. F. (2001). Industrial Poultry: New Concepts of Materials, Conceptions and Constructive Techniques Available for Brazilian Poultry Sheds. Brazilian Journal of Poultry Science, 3(1), 1-26.

UBABEF (Brazilian Union of Poultry). (2011). The saga of the Brazilian poultry industry: How Brazil has become the world's largest exporter of chicken meat. Retrieved from http://abpa-br.com.br/files/publicac oes/fcc1856de5f036bb47a8a246a0781e26.pdf

\section{Copyrights}

Copyright for this article is retained by the author(s), with first publication rights granted to the journal.

This is an open-access article distributed under the terms and conditions of the Creative Commons Attribution license (http://creativecommons.org/licenses/by/4.0/). 